\title{
Developing Pre-Service Teachers' Mathematics TPACK through an Integrated Pedagogical Course
}

\author{
Nabil Assadi, Wafiq Hibi \\ Sakhnin College, Sakhnin, Israel \\ Email: nabilgood1@yahoo.com
}

How to cite this paper: Assadi, N., \& Hibi, W. (2020). Developing Pre-Service Teachers' Mathematics TPACK through an Integrated Pedagogical Course. Creative Education, 11, 1890-1905.

https://doi.org/10.4236/ce.2020.1110138

Received: September 5, 2020

Accepted: October 13, 2020

Published: October 16, 2020

Copyright $\odot 2020$ by author(s) and Scientific Research Publishing Inc. This work is licensed under the Creative Commons Attribution International License (CC BY 4.0).

http://creativecommons.org/licenses/by/4.0/

\section{(c) (i) Open Access}

\begin{abstract}
Lesson planning and presentation are regarded as an effective method that allows pre-service teachers to gain experience in the instructional processes and improve teaching skills. Lesson Portfolio and Presentations, not only is utilized as a method for increasing the quality of a teacher's education, but also used to research the Technological Pedagogical Content Knowledge (TPACK) framework. The purpose was to investigate changes in pre-service teachers' TPACK from their lesson portfolio and presentation practices conducted under the TPACK framework. The participants are 22 third-year pre-service teachers. An analysis was performed based on specific concepts from the projects, which had been developed to reveal the changes in pre-service teachers' TPACK components. Content analysis was used to analyze the observation forms, self-evaluations, videos and interviews. The study's findings indicate that pre-service teachers use GeoGebra tools to attain what they had specified in their instructional plans. When considered in terms of the TPACK components, pre-service teachers made noticeable progress.
\end{abstract}

\section{Keywords}

Technological Pedagogical Content Knowledge, Mathematics Education, Lesson Presentation, Pre-Service Teacher, Technology Integration GeoGebra

\section{Introduction}

In Pedagogy Courses, PSTs are often asked to create a lesson plan and present it to their peers in class, with the presenting PST playing the role of teacher, and the others playing the role of their students. Accordingly, we asked every PST in an integrated course to present such projects twice over the course of the seme- 
ster, each time creating and presenting a lesson that made use of GeoGebra software. In assessing the PSTs' projects, we wished to determine: a) how the projects reflected the PSTs' mastery of the mathematical content; b) how they reflected their pedagogical knowledge; c) how they were choosing to integrate the GeoGebra software into their lesson. We used the students' projects, in conjuction with a variety of other research tools, to assess the extent and manner of the PSTs' integration of GeoGebra into their teaching. A vast literature on this subject provides a broad scope of theories, methods, and interpretations related to the educational potential of technologies to aid mathematics instruction.

In our study, we focus on integrating GeoGebra (mathematics teaching software) during a Pedagogical Course and assess its integration in Pre-Service Teachers' teaching concepts projects.

As technology becomes more widespread in education, new technological tools guided educators' research methods, practices, and questions, particularly mathematicians (Artigue, 2002). The use of technological tools is significant, especially in ensuring the visualization of mathematical concepts (Metaxas \& Karagiannidou, 2010), and allows multiple representations of mathematical concepts (O'Callaghan, 1998). With technology use becoming popular in mathematics education, the mathematics curricula of several countries have emphasized the necessity and importance of mathematical instruction through technology. Integrating computer-assisted education with mathematics education depends on numerous factors such as a school's technological infrastructure, whether it has the required educational software and student/teacher resources, students' and teachers' attitudes towards technology, and teachers' education. Teacher education is considered the most crucial element for accurately integrating technological tools within the instructional process, and some research has focused on this (Lawless \& Pellegrino, 2007). Indeed, teachers can integrate technological tools accurately and efficiently by understanding the pedagogy of using these tools and using them according to the class (Harris et al., 2009). In the literature, teachers' knowledge of technological pedagogy (i.e., how a concept is learned and taught using technology) is defined as Technological Pedagogical Content Knowledge (TPACK) (Niess, 2005).

TPACK is the interaction and intersection of technological, pedagogical, and content knowledge (Koehler, Mishra, \& Yahya, 2007; Mishra \& Koehler, 2006). Taking pedagogical content knowledge as the base, TPACK involves different components such as instructional strategies and knowing how to assess/evaluate and understand students and the curricula (Angeli \& Valanides, 2009).

The information structures described in the TPACK model define diverse types of technological integration and provide a basic theoretical construct. TPACK's construct aims to help develop better techniques that define how theoretical information on technology can be put into practice. Studies have concentrated on investigating teachers' knowledge and competences using the TPACK framework (Angeli \& Valanides, 2009; Mishra \& Koehler, 2006). Teachers are 
said to come to a better point in understanding technological integration's level of potential when they gain the necessary practicality (Harris et al., 2009). Teachers need to consider all components rather than just one aspect so that instruction can be performed by simultaneously combining technological, pedagogical, and content knowledge in the TPACK construct. According to Harris et al. (2009), teachers should be able to navigate through content, pedagogical, and technological knowledge and their complex relations within specific contexts.

To sum up, providing teachers with technologically equipped classrooms, access to technology, and positive attitudes under the technological integration model will not guarantee technological integration in classrooms. In addition to good content, technological, and pedagogical knowledge, integrating the knowledge and performance of practical applications is vital for achieving technological integration. As mentioned above, TPACK requires thinking about this knowledge in multiple ways, not just one. Hence, as stated by Niess (2005), Pre-service teachers need a well-developed information base and the ability to apply the subject to related areas.

Lesson presentations, utilized as a method for increase the quality of teacher education, have also been used in TPACK research studies (Cavin, 2007; Cavin \& Fernandez, 2007; Kafyulilo, 2010; Taşar \& Timur, 2010). Lesson presentations are regarded as an effective method that allows pre-service teachers to gain experience in instructional processes (Görgen, 2003) and improve teaching skills in environments similar to real classrooms (Kpanja, 2001). Through Lesson presentations, pre-service teachers gain experience by observing other pre-service teachers' instruction alongside their own (Görgen, 2003).

According to the TPACK model, teachers need to have a general knowledge of pedagogical content and technological subjects and understand the interactions and relations among these knowledge types. For this cause having relative knowledge and skills is not enough on its own for being an effective teacher of technological use (Koehler et al., 2007; Mishra \& Koehler, 2006). According to Koehler et al. (2007: p. 741), "At the heart of TPACK is the dynamic, transactional relationship between content, pedagogy, and technology. Good teaching with technology requires understanding the mutually reinforcing relationships between all three elements taken together to develop appropriate, context-specific strategies, and representations." This approach addresses the TPACK theoretical model in pre-service education, whereas emphasizing the importance of Lesson presentations allows for developing strategies and presentations specific to the learning environment. When reduced to content, pre-service teachers should have an extensive understanding of TPACK to teach mathematics.

In studies in the literature investigating the effect of Lesson presentations on teachers/pre-service teachers' TPACK in the literature, pre-service teachers have been revealed to acquire an awareness of the details necessary for performing instruction with technology, how to use traditional instruction methods along with technology in student-centered learning environments, and how Lesson presen- 
tations positively impact their general TPACK development (Cavin, 2007; Cavin \& Fernandez, 2007; Kafyulilo, 2010). However, in the literature, content seems to be generally neglected in terms of technological pedagogical content knowledge and applications that pre-service teachers are to be provided with. Based on this consideration, this research can fill a gap in the field by examining pre-service mathematics teachers' change in TPACK from Lesson presentations practices and providing suggestions along a theoretical framework integrated with the aspect of the content.

\section{Literature Review: Measuring Technology Integration in Education}

Teaching Concepts in Practice: Although researchers recognize the potential of having students use computers for exploring mathematics, many teachers have not incorporated technology beyond the use of standard calculators (Zbiek, Heid, Blume, \& Dick, 2007). Research also shows that although many math teachers report that they integrate technology, most often report low technology usage and minimal use of drill-and-practice software (Purcell et al., 2013). High-level technology use is typically associated with student-centered or constructivist practices (An \& Reigeluth, 2011). Technology-related classroom management is a challenge for pre-service teachers and in-service teachers (Hew \& Brush, 2007; Lim et al., 2003).

Procedural Knowledge vs. Conceptual Knowledge: Ma's (2010) and other researchers observed that teachers focused on teaching rules and procedures in math. Teachers in countries whose students get higher math scores spent more teaching time making connections between math topics and concepts. Researchers have documented the same limited content knowledge among pre-service teachers (Ma, 2010; Philipp et al., 2007).

As technology evolves, there is an increasing demand for teachers to develop technology-based lessons appropriate to $21^{\text {st }}$-century skills. Thus, pre-service teachers must be trained and master the practical content knowledge and the pedagogical skills needed to integrate technology in mathematic lessons.

\section{TPACK Components' Importance in Mathematics Teaching and Learning with GeoGebra}

\section{Why GeoGebra}

Every option is more focused than the other in different aspects of math in secondary education. GeoGebra have advantages in manipulation of Geometry that easy presentation and exploration of Geometric Concepts and examples

In Israel The Israeli ministry of education has no unified policy regarding preference to specific educational aids, but the use of the said program is recommended due to the following:

- GeoGebra software program is known in Israel and has been found appropriate for Math teaching, The High school Teachers organization publishes 
GeoGebra based lessons, The program is also in everyday use in Arabic speaking countries, the program is commonly used by teachers and lecturers of the Israeli Arabic sector.

\section{GeoGebra and multiple representations of concepts:}

Using multiple representations in math teaching emphasizes various aspects of the same concept, can actualize a more conceptual understanding of students through different learning styles (Berthold et al., 2009; Mallet, 2007). One of the advantages of GeoGebra it's the multirepresentation of concepts possibilities. But, studies on multiple representations highlight that, when the use of technologies in instruction is not planned carefully, they may pose an impediment to learning instead of supporting it (Berthold et al., 2009; Mallet, 2007). In these respects, the importance of pre-service and in-service teacher education on the efficient use of multiple representations in teaching becomes apparent. Teachers and pre-service teachers, as educated individuals, can efficiently teach multiple representations by providing them with technological facilities that support their conceptual understanding.

GeoGebra and student difficulties regarding concepts and students misconceptions:

Developing conceptual understanding, being a primary concern of mathematics education, can be challenging to achieve because the strength of the prerequisite relationship affects interpretation, and a student who has difficulty/misconceptions with a concept can have difficulty succeeding later on in related concepts (Yetkin, 2003). Therefore, these difficulties need to be eliminated right away when identified among students (Duval, 1999). Structuring an efficient learning environment has been suggested for eliminating student difficulties. By using technology, many concepts can be visualized through multiple representations, positively supporting conceptual learning and mathematical thinking, thus addressing the difficulties students frequently experience (Selden, Dubinsky, Harel, \& Hitt, 2003; Yerushalmy, 1991). Meanwhile, handling student difficulties efficiently with technology is possible by providing this knowledge and skills to teachers and pre-service teachers.

GeoGebra and the methods and strategies for concept teaching:

The methods used in mathematics teaching include direct instruction, question \& answer; discovery; discussion; instruction through analysis and demonstration; instruction using scenarios; and instruction using games, projects, cooperative learning, and problem-solving. Using technological aspects to shape the composition of instructional methods and strategies addressed within pedagogical content knowledge (Shulman, 1986) is essential. Considering that technology has become an inseparable part of education (and more specific instruction), how the component of instructional strategies and methods should be handled in the presence of technology, how the presence of technology shapes these strategies and methods, and the role of the teacher in this process are all very critical for efficient education and instruction. Aside from providing ap- 
propriate strategies and methods for ensuring students' meaningful conceptual learning, appropriate technologies should also be used for an effective process. In this context, a teacher's preferred strategy/method can impact how, for what purpose, and at what level technology is used (Hughes, 2005). For instance, teachers who adopt a presentation as a method can use the technology at hand to this end. Thus for students' conceptual learning, pre-service teachers and in-service teachers need also to use technological tools to establish the relationships among concepts or representations by utilizing various tools. Because technology-usage levels and purposes are influenced by preferred instructional methods/strategies, those in pre-service and in-service teacher education need to be provided with these usage levels and knowledge.

\section{Geogebra and concept assessment-evaluation:}

Paralleling the changes in curricula, instructional methods, and techniques, assessment, and evaluation styles have also seen changes. In recent years, two different assessment types (i.e., summative and formative) have been debated (Linchevski, Kutscher, \& Olivier, 1999). While summative assessment-evaluation is used for ranking students according to specific criteria in order to identify those who have completed a given instructional process (Bloom, Hastings, \& Madaus, 1971), formative assessment-evaluation aims to monitor students' progress within the instruction to ensure adjustments in teaching and learning following students' failures or successes (Gronlund, 2006).

Knowledge and skills on assessment-evaluation have come into play when use GeoGebra. Technology research has shown assessment and evaluation to be ignored (Kissane, Bradley, \& Kemp, 1994). Considering its summative and formative aspects, TPACK emphasizes how assessing/evaluating technological tools should be done. Because students shape their learning styles by how they are assessed and evaluated, having students be evaluated through the learning outputs of ordinary teaching unassisted by technology is insufficient for the end of technology-assisted teaching. Evaluating students who are taught with the help of technology should be addressed in pre-service and in-service teacher's education.

Teaching concepts on the curriculum using GeoGebra: Curriculum knowledge is handled under pedagogical content knowledge (Park \& Oliver, 2008). This knowledge offers guidance on how deep and how far to address the concepts being taught (Rasinen, 2003). The depth to which a concept should be taught is essential, especially in terms of teachers in-class decisions and insight into what students need to know about the concept being taught for the academic year and the years ahead (Magnusson et al., 1999). Several studies on mathematics teaching have drawn attention to the vital role of depth in teaching concepts (Stump, 2001). Teaching Concepts knowledge becomes even more critical when integrating technology. Many studies have argued that addressing advanced conceptual relations in simple concepts mainly affects how advanced concepts are handled. Teachers superficially utilize educational technologies, 
and students actualize low-level learning when instruction is neither in-depth nor diversified enough for them to succeed (Groff \& Mouza, 2008; Levin \& Wadmany, 2008). The systematic exclusion from the curriculum of application examples on educational technologies in teaching indicates a significant problem. The concepts addressed in mathematics education studies have often been observed outside the curriculum (Metaxas \& Karagiannidou, 2010). Based on this point, emphasis should be placed on teachers and pre-service teachers to not perform activities in technology-assisted instruction that exceeds the curriculum; otherwise, this situation can cause failure in pre-service and in-service teachers' educational learning outputs.

\section{Research Aims}

\section{Conceptual Framework of the Study}

According to Özmantar et al. (2010), the components of pedagogical and math knowledge, listed below, are examined within the context of the GeoGebra program:

1) Multiple representations of concepts

2) Identifying and addressing students' difficulties and misconceptions regarding the new concepts

3) Using built-in methods and strategies to teach concepts

4) Using tools enabling concept assessment

\section{Research Questions}

1) How, if at all, do the PSTs use GeoGebra to teach Concepts using multiple representations of a concept?

2) How, if at all, do PSTs use GeoGebra as a means of deriving student difficulties from misconceptions?

3) How, if at all, do PSTs use GeoGebra's concerning methods and strategies for concept instruction?

4) How, if at all, do PSTs use GeoGebra to assess student learning?

5) How, if at all, do PSTs integrate the use of GeoGebra in teaching concepts across all the curriculum?

\section{Participants and Method}

The research participants were 22 PSTs in years second - fourth enrolled in an undergraduate mathematics teaching certification program at Sakhnin College.

The study focuses on how the PSTs' skills in Content, Pedagogy, and Technology Integration were reflected in their projects.

\section{Process}

During a standard pedagogical course, a portfolio is usually prepared to contain the programmed class, the strategy to be used, as it connects to the annual program.

In these courses the microteaching (Lesson presentation) procedure was used.

The course adapted the instruments used in the previous courses with specific 
changes and additions. First, the other teachers gave feedback using an dedicated observation form The process of analyzing the projects was extended, and the instructor interview and the use of the video were added.

GeoGebra also allows us to see the log of the scheduled class.

In the second half of the course, each PST performed a second project, underwent the same procedure.

\section{Main Research Tools}

We asked every PST in the integrated course to present such projects twice over the semester, creating and presenting a lesson using GeoGebra software.

The tools are a combination of qualitative tools (Voogt et al., 2012).

Tools: observation form, video recordings, interviews, lesson plans, self-assessment form, and GeoGebra files.

\section{Observation form}

Each PST project presented was evaluated within the context of TPACK by the other PSTs [peer evaluation] using an observation form. This measure was taken to increase the effectiveness of the project.

\section{Project videos}

Each project was recorded by two mobile-phone cameras, one focusing on the presenter's communication and the other on his/her lecture. The videos were recorded to examine the change(s) of each PST along the TPACK axis and to enable everyone to review their project videos, so they could self-evaluate more objectively and in more detail.

\section{Self-evaluation form}

The PSTs examined their peers' evaluations using the observation forms and project videos. They completed a self-evaluation form, which was used to ensure that they would see their instruction in a more detailed and focused way by observing and judging their instruction. The self-evaluation form contains questions in the same areas as the observation form, with the additional requirement of evaluating the general ways and limits that technology offers for instruction. This form comprised more than 20 items that were created by re-shaping the observation form to enable self-evaluation. For example, the following questions were asked regarding GeoGebra and the methods and strategies in concept instruction:

1) Which methods and strategies did you prefer to use in your instruction? Please explain your reasons in detail.

2) To what purpose and level were you able to use GeoGebra for your preferred methods and strategies? Please explain how the purpose and level of use affected your instruction and what you would change?

3) How did the GeoGebra affect your chosen methods and strategies? Please explain your reasons in detail.

\section{Interviews}

The PSTs were interviewed personally on the topic of their project self-evaluation. The interviews were conducted face-to-face so the PSTs could explain 
and/or clarify aspects of their self-evaluations that were unclear or required interpretation.

\section{Instructional plans}

The PSTs prepared their instructional plans according to the goals they had set for their projects. Each was given a specific instruction-plan format. After their first projects (end of the Introductory GeoGebra section), each of the PSTs examined the evaluations made by their peers on the observation forms and watched their project video. They then wrote a self-evaluation based on the same TPACK components appearing in the observation form.

The PSTs revised their instructional plans parallel to their self-evaluations after the first project presentations and submitted the revised instructional plans for their second projects.

\section{Findings}

The findings will be divided according to the research questions presented above.

How, if at all, do the PSTs use GeoGebra to teach Concepts using multiple representations of a concept?

In the first project, the rate of GeoGebra usage in different representations was found insufficient.

In the second project Participants increased the specified representations and the extent to which GeoGebra was used. The semi-structured interviews with the PSTs concerning the self-assessments of their first project revealed that most of them did not benefit from GeoGebra's tools for interrelating representations.

How, if at all, do the PSTs use GeoGebra as a means of deriving student difficulties from misconceptions?

The PSTs' lesson plans of their first projects, including references to objectives, difficulties, misconceptions, errors, and interrelations, reveal uncertainty. The methods used to address these concepts in practice, and the fact that most participants did not benefit from the computer software when planning their first project are also intriguing.

A review of the PSTs' first and second projects shows that most of them cannot make efficient use of the computer software to overcome student difficulties. Although most PSTs acknowledged the computer software as being convenient to this effect, the fact that most of the PSTs focused on graph difficulties when discussing their second projects suggests that difficulties addressed regarding the software type might have been limited.

Another intriguing finding in this context is that the PSTs did not consider the potential problems students might face in GeoGebra use.

How, if at all, do the PSTs use GeoGebra's concerning methods and strategies for concept teaching?

In examining the methods and strategies preferred by the PSTs in their lessons, the results reveal no significant change in the tools they used between their first and second projects. 
PST's uses more than one strategy in their projects.

The most preferred methods and strategies used by PSTs included learning by discovery, directed teaching, discussion, questioning, and interaction, brainstorming in both their first and second projects.

Analysis of the levels of the PSTs' integration of GeoGebra $n$ their methods and strategies showed that increased in the second projects, probably due to the PSTs' exposure to their peers' assessment and their self-assessment of their first project.

How, if at all, do PSTs use GeoGebra to assess "student" learning?

PSTs used different assessment tools for different purposes in their first projects. What drew my attention was that only six pre-service teachers used GeoGebra in the assessment-evaluation process.

Most participating PSTs had integrated technology and formative assessmentevaluations into their second (final) projects.

The analyses examined in-depth how the PSTs used computer software and assessment-evaluation tools in their instructional plans for formative and/or summative purposes during the work on their personal projects, and how they benefited from the technology in this stage.

We can sum up that; in an examination of the assessment-evaluation tools used by the PSTs and their purposes; it appears that the main benefit the PSTs derived from learning to use the technology was the use of formative methods in their assessment-evaluation processes for the second projects.

How, if at all, do the PSTs integrate the use of GeoGebra in their teaching concepts across all the curriculum

The PSTs' first projects and lesson plans show that most of them tend to prefer goals involving the curriculum statement: "information and communication technologies can be benefitted from." I also found that the PSTs did not present the objectives they had initially set for using GeoGebra for concept teaching and multiple concept representations. Analysis of the goals stated in the lesson plans the PSTs made for the first projects revealed that eight PSTs appear to have mistakenly included activities in their projects above the relevant grade/age-group targeted by the curriculum.

\section{Discussion}

\section{Teaching Concepts with GeoGebra}

How, if at all, do PSTs use GeoGebra to teach Concepts using multiple representations of a concept?

Examining the PSTs' lesson plans for the first projects showed that, though many participants used different representations, most did not interrelate them. In contrast, inter-relations between representations are an essential aspect of understanding the subjects conceptually.

An examination of peer- and self-assessments shows that the participants had devoted enhanced efforts to the issue of interrelating representations in the 
second project.

Considering this study outcome, one could say that the PSTs did not derive much benefit from this component of GeoGebra, especially about interrelating representations.

How, if at all, do PSTs use GeoGebra as a means of deriving student difficulties from misconceptions?

An examination of PSTs' lesson plans for the first projects reveals that they could not distinguish between conceptual and mental errors or misconceptions. Also, most of the participants did not benefit from the computer software to plan how to address these concepts is intriguing. PSTs' knowledge of these concepts is essential; only with this knowledge will they develop productive and useful strategies for readdressing students' understandings (Bingölbali \& Özmantar, 2009).

The only possible conclusion is that the PSTs should be provided with environments where they can select the appropriate software to overcome conceptrelated difficulties that prevent them from making optimal plans.

How, if at all, do the PSTs use GeoGebra's concerning methods and strategies for concept instruction?

The most frequent instructional methods and strategies used by PSTs in practice for both the first and second projects were: discovery, directed teaching, discussion, questioning, and interaction, brainstorming. Data analysis shows the PSTs made progress in integrating technology to develop specific skills, using GeoGebra software and its various useful tools.

The participants' progress was shown by an increase in the number of Level 3 activities performed in their second projects, affected by inputs received employing peer- and self-assessments of the first projects. According to Hughes (2005), achieving transformation and quality learning through technology is possible when technology is used at the third level, alongside appropriate methods and strategies. The fact that the participants started to use technology more efficiently is a significant indicator of progress in this component.

How, if at all, do PSTs use GeoGebra to assess/evaluate student learning?

Analysis of data obtained in the context of TPACK's assessment-evaluation component revealed that the PSTs improved their skills in locating relevant information of various GeoGebra tools used for assessment-evaluation and using it in technology-assisted environments for formative and/or summative purposes. The PSTs' lesson plans for their second projects show that their use of multiple assessment-evaluation tools according to their different purposes was quite remarkable.

How, if at all, do PSTs integrate the use of GeoGebra in their teaching concepts across all the curriculum?

Analysis of the data gathered by qualitative methods indicates that PSTs tend to prefer specific curriculum contents involving the statement "information and communication technologies can be used" to achieve technological integration. 
PSTs did not present the objectives set for GeoGebra use as part of their lesson plan for the concept they had reflected on, nor for concepts of multiple representations and misconceptions. Thus, generally speaking, the PSTs identified some newly-acquired skills while addressing curriculum-related attainments.

A review of the study's application of process contents reveals the importance of investigation and discussion of methodology: how attainments on the vertical axis are taught to a specific grade/age-group. The outcome shed light on is the lack of materials used in technology-assisted mathematics teaching designed according to the curriculum. By including technology in the process, teaching and learning are fundamentally altered (Kieran \& Drijvers, 2006). These leads teachers in the field and the research participants to use available resources as GeoGebra Applets.

In our case, some PSTs pointed out the lack of activities aimed at practicing the use of GeoGebra to support instruction, either within the program or in the course materials. They claimed that they could not create efficient projects because they did not use any GeoGebra resource (applets, worksheets, etc.).

\section{Conclusion}

Consequently, the pre-service teachers used technological tools to achieve the goals they specified in their instructional plans. When considered within this study's TPACK framework, the findings show the pre-service teachers to have made noteworthy progress along the axis of TPACK components. Efficient Lesson presentations practice plays a significant role in this progress:

1) Allowing pre-service teachers to monitor their in-class performance (Wakwinji, 2011),

2) Allowing them to gain experience on what to do or not do when instructing in real classroom settings (Marulcu \& Dedetürk, 2014),

3) Allowing other participants to monitor and evaluate,

4) Enable self-evaluation (Fernandez, 2005; Kpanja, 2001; Peker, 2009)

These indicate the shortcomings and proposed solutions presented in the discussion, as well as the effectiveness of project-based learning, including Lesson presentations programs based on the TPACK conceptual framework. Furthermore, developing instructions to ensure that this Lesson presentations method can be applied in real classroom settings and also be applied in undergraduate lessons (including school experience and teaching practices) are recommended.

GeoGebra software should be employed as a supportive and complementary activity for pre-service teachers' education. The integrated didactic course investigated in this study has been shown to improve mathematical content knowledge, enhance technology integration among pre-service teachers, and contribute to Mathematics Pedagogy research in Israel.

However, in every research question, there is some discrepancy between results and conclusion, as described in the discussion section.

The results of this study clarify the implications of GeoGebra use for teaching 
and learning, showing its:

1) Viability: The study tools are feasible for implementation and use in preservice teachers' supplementary courses.

2) Adaptability: The tools are adaptable in multiple contexts.

\section{Research Limitations}

Due to the modest number of participants, the study's results cannot be generalized.

\section{Suggestions}

Pedagogical integrated courses may be planned in the last year of the degree for training PSTs and focused in the integration of GeoGebra in their future lessons. The objective of the proposed course is to enhance the techno-pedagogical qualifications of future Math teachers. The scope of the course could be expanded and rearranged to provide on-the-job training for Math teachers who want to enhance their techno-pedagogical qualifications. Thus, Math teachers and preservice teachers would be encouraged to employ technology in their lessons.

\section{Recommendations}

If GeoGebra is introduced in the pre-service teachers curricula as the leading digital tool, GeoGebra integration (ICT) in pedagogical courses should be made mandatory. The tools developed in this study should be used in further research (academic and field level).

\section{Conflicts of Interest}

The authors declare no conflicts of interest regarding the publication of this paper.

\section{References}

An, Y.-J., \& Reigeluth, C. (2011). Creating Technology-Enhanced, Learner-Centred Classrooms: K-12 Teachers' Beliefs, Perceptions, Barriers, and Support Needs. Journal of Digital Learning in Teacher Education, 28, 54-62. https://doi.org/10.1080/21532974.2011.10784681

Angeli, C., \& Valanides, N. (2009). Epistemological and Methodological Issues for the Conceptualization, Development, and Assessment of CT-TPCK: Advances in Technological Pedagogical Content Knowledge (TPCK). Computers \& Education, 52, 154 168. https://doi.org/10.1016/j.compedu.2008.07.006

Artigue, M. (2002). Learning Mathematics in a CAS Environment: The Genesis of a Reflection about Instrumentation and the Dialectics between Technical and Conceptual Work. International Journal of Computers for Mathematical Learning, 7, 245-274. https://doi.org/10.1023/A:1022103903080

Berthold, K., Eysink, T. H. S., \& Renkl, A. (2009). Assisting Self-Explanation Prompts Are More Effective than Open Prompts When Learning with Multiple Representations. Instructional Science, 37, 345-363. https://doi.org/10.1007/s11251-008-9051-Z

Bingölbali, E., \& Özmantar, M. F. (2009). Mathematical Difficulties in Elementary Schools 
and Solution Proposals. In E. Bingölbali, \& M. F. Özmantar (Eds.), Mathematical Misconceptions: Reasons and Seeking Solutions (pp. 1-30). Ankara: Pegem Akademi.

Bloom, B. S., Hastings, J. T., \& Madaus, G. F. (1971). Handbook on the Formative and Summative Evaluation of Student Learning. New York: McGraw-Hill.

Cavin, R. M. (2007). Developing Technological Pedagogical Content Knowledge in PreService Teachers through Microteaching Lesson Study. Doctoral Dissertation, Tallahassee, FL: The Florida State University.

Cavin, R. M., \& Fernández, M. (2007). Developing Technological Pedagogical Content Knowledge in Pre-Service Math and Science Teachers. In R. Carlsen, K. McFerrin, J. Price, R. Weber, \& D. Willis (Eds.), Society for Technology Information and Teacher Education International Conference Proceedings 2007 (pp. 2180-2186). Norfolk, VA: Association for the Advancement of Computing in Education.

Duval, R. (1999). Representation, Vision, and Visualization: Cognitive Functions in Mathematical Thinking. Basic Issues for Learning. In Proceedings of the Twenty-First Annual Meeting of the North American Chapter of the International Group for the Psychology of Mathematics Education (pp. 30-26). Cuernavaca.

Fernandez, M. L. (2005). Learning through Microteaching Lesson Study in Teacher Preparation. Action in Teacher Education, 26, 37-47. https://doi.org/10.1080/01626620.2005.10463341

Görgen, G. (2003). Effect of Micro-Instruction Practices on Pre-Service Teachers' Opinions on Instruction $\mathrm{n}$ the Classroom. Hacettepe University Faculty of Education Journal, 24, 56-63.

Groff, J., \& Mouza, C. (2008). A Framework for Addressing Challenges to Classroom Technology Use. American Association of Clinical Endocrinologists Journal, 16, 21-46.

Gronlund, N. (2006). Assessment of Student Achievement (8th ed.). Boston, MA: Pearson.

Harris, J., Mishra, P., \& Koehler, M. J. (2009). Teachers' Technological Pedagogical Content Knowledge and Learning Activity Types: Curriculum-Based Technology Integration Reframed. Journal of Research on Technology in Education, 41, 393-416. https://doi.org/10.1080/15391523.2009.10782536

Hew, K., \& Brush, T. (2007). Integrating Technology into K-12 Teaching and Learning: Current Knowledge Gaps and Recommendations for Future Research. Educational Technology Research and Development, 55, 223-252.

https://doi.org/10.1007/s11423-006-9022-5

Hughes, J. (2005). The Role of Teacher Knowledge and Learning Experiences in Forming Technology-Integrated Pedagogy. Journal of Technology and Teacher Education, 13, 277-302.

Kafyulilo, A. (2010). Practical Use of ICT in Science and Mathematics Teachers' Training at DUCE: An Analysis of Prospective Teachers' Technological Pedagogical Content Knowledge. Master's Thesis, Twente: University of Twente.

Kissane, B., Bradley, J., \& Kemp, M. (1994). Graphics Calculators, Equity, and Assessment. Australian Senior Mathematics Journal, 8, 31-43.

Koehler, M. J., Mishra, P., \& Yahya, K. (2007). Tracing the Development of Teacher Knowledge in a Design Seminar: Integrating Content, Pedagogy, and Technology. Computers \& Education, 49, 740-762. https://doi.org/10.1016/j.compedu.2005.11.012

Kpanja, E. (2001). A Study of the Effects of Video Tape Recording in Microteaching Training. British Journal of Educational Technology, 32, 483-486.

https://doi.org/10.1111/1467-8535.00215

Lawless, K. A., \& Pellegrino, J. W. (2007). Professional Development in Integrating Tech- 
nology into Teaching and Learning: Known, Unknowns, and Ways to Pursue Better Questions and Answers. Review of Educational Research, 77, 575-614. https://doi.org/10.3102/0034654307309921

Levin, T., \& Wadmany, R. (2008). Teachers' Views on Factors Affecting Effective Integration of Information Technology in the Classroom: Developmental Scenery. Journal of Technology and Teacher Education, 16, 233-263.

Lim, C. P., Teo, Y. H., Wong, P., Khine, M. S., Chai, C. S., \& Divaharan, S. (2003). Creating a Conducive Learning Environment for the Effective Integration of CT: Classroom Management Issues. Journal of Interactive Learning Research, 14, 405-423.

Linchevski, L., Kutscher, B., \& Olivier, A. (1999). Assessment in Support of Equity. In Fifth Annual Congress of the South Africa Association for Mathematics Education Proceedings (Vol. 1, pp. 155-167). Port Elizabeth: Port Elizabeth Technikon.

Ma, L. (2010). Knowing and Teaching Elementary Mathematics: Teachers' Understanding of Fundamental Mathematics in China and the United States (10th ed.). Mahwah, NJ: Routledge. https://doi.org/10.4324/9780203856345

Magnusson, S., Krajcik, J., \& Borko, H. (1999). Nature Sources and Development of Pedagogical Content Knowledge for Science Teaching. In J. Gess-Newsome, \& N. G. Lederman (Eds.), Examining Pedagogical Content Knowledge: The Construct and Its Implications for Science Education (pp. 95-132). Dordrecht: Kluwer Academic Publishers. https://doi.org/10.1007/0-306-47217-1_4

Mallet, D. G. (2007). Multiple Representations for Systems of Linear Equations via the Computer Algebra System Maple. International Electronic Journal of Mathematics Education, 1, 16-31.

Marulcu, G., \& Dedetürk, A. (2014). Preservice Science Teachers' Practices of Micro-Instruction Method: An Action Research. Mustafa Kemal University Journal of Social Sciences Institute, 11, 353-372.

Metaxas, N., \& Karagiannidou, A. (2010). When Two Circles Determine a Triangle. Discovering and Proving a Geometrical Condition in a Computer Environment. International Journal of Computers for Mathematical Learning, 15, 63-71. https://doi.org/10.1007/s10758-009-9146-x

Mishra, P., \& Koehler, M. J. (2006). Technological Pedagogical Content Knowledge: A Framework for Teacher Knowledge. Teachers College Record, 108, 1017-1054. https://doi.org/10.1111/j.1467-9620.2006.00684.x

Niess, M. L. (2005). Preparing Teachers to Teach Science and Mathematics with Technology: Developing a Technology Pedagogical Content Knowledge. Teaching and Teacher Education, 21, 509-523. https://doi.org/10.1016/j.tate.2005.03.006

O'Callaghan, B. R. (1998). Computer-Intensive Algebra and Students' Conceptual Knowledge of Functions. Journal for Research in Mathematics Education, 29, 21-40. https://doi.org/10.5951/jresematheduc.29.1.0021

Özmantar, M. F., Akkoç, H., Bngölbali, E., Demir, S., \& Ergene, B. (2010). Pre-Service Mathematics Teachers' Use of Multiple Representations in Technology Rich Environments. Eurasia Journal of Mathematics, Science \& Technology Education, 6, 19-36. https://doi.org/10.12973/ejmste/75224

Park, S., \& Oliver, J. S. (2008). Revisiting the Conceptualisation of Pedagogical Content Knowledge (PCK): PCK as a Conceptual Tool to Understand Teachers as Professionals. Research in Science Education, 38, 261-284. https://doi.org/10.1007/s11165-007-9049-6

Peker, M. (2009). The Use of Expanded Microteaching for Reducing Preservice Teachers' Teaching Anxiety about Mathematics. Scientific Research and Essay, 4, 872-880. https://doi.org/10.12973/ejmste/75284 
Philipp, R. A., Ambrose, R., Lamb, L. L. C., Sowder, J. T., Schappelle, B. P., Sowder, L., \& Chauvot, J. (2007). Effects of Early Field Experiences on the Mathematical Content Knowledge and Beliefs of Prospective Elementary School Teachers: An Experimental Study. Journal for Research in Mathematics Education, 38, 438-476.

Purcell, K., Heaps, A., Buchanan, J., \& Friedrich, L. (2013). How Teachers Are Using Technology at Home and in Their Classrooms. Washington DC: Pew Research Center's Internet and American Life Project.

Rasinen, A. (2003). An Analysis of the Technology Education Curriculum of Six Countries. Journal of Technology Education, 15, 31-47. https://doi.org/10.21061/jte.v15i1.a.3

Selden, A., Dubinsky, E., Harel, G., \& Hitt, F. (2003) Research in Collegiate Mathematics Education $V($ Vol. 12). Providence, RI: American Mathematical Society. https://doi.org/10.3102/0013189X015002004

Shulman, L. S. (1986). Those Who Understand: Knowledge Growth in Teaching. Educational Researcher, 15, 4-14.

Stump, S. L. (2001). Developing Pre-Service Teachers' Pedagogical Content Knowledge of Slope. Journal of Mathematical Behavior, 20, 207-227. https://doi.org/10.1016/S0732-3123(01)00071-2

Voogt, J., Fisser, P., Pareja Roblin N., Tondeur, J., \& van Braak, J. (2012). Technological Pedagogical Content Knowledge: A Review of the Literature. Journal of Computer-Assisted Learning, 29, 109-121. https://doi.org/10.1111/j.1365-2729.2012.00487.x

Wakwinji, J. (2011). Exploring How a Workshop Approach Helps Mathematics Teachers Start to Develop Technological Pedagogical Content Knowledge. Master's Thesis, Amsterdam: Faculty of Science Universiteit van Amsterdam.

Yerushalmy, M. (1991). Student Perceptions of Aspects of Algebraic Function Using Multiple Representation Software. Journal of Computer Assisted Learning, 7, 42-57. https://doi.org/10.1111/j.1365-2729.1991.tb00223.x

Yetkin, E. (2003). Student Difficulties in Learning Elementary Mathematics. Columbus, $\mathrm{OH}$ : ERIC Clearinghouse for Science, Mathematics and Environmental Education.

Zbiek, R. M., Heid, M. K., Blume, G. W., \& Dick, T. P. (2007). Research on Technology in Mathematics Education: A Perspective of Constructs. In F. Lester (Ed.), Second Handbook of Research on Mathematics Teaching and Learning (pp. 1169-1208). Reston, VA: National Council of Teachers of Mathematics. 